\title{
Apocalyptic Incidents during the Mongol Invasions David Cook
}

\section{Muslim Views of the Invasions}

By any standards the Mongol invasions, which started (at least from the Muslim point of view) in 1219, when Ghenghis Khan conquered the area of Transoxiania, and culminated with the destruction of Baghdad and the murder of the caliph in 1258, were an apocalyptic event. No one knows for sure exactly how many people were killed, nor how much property or what percentage of the Islamic cultural heritage was destroyed during this time period, but many scholars of the Muslim world say that this event was of such apocalyptic magnitude that the area of Transoxiania, Persia and Iraq never fully recovered from it, and even today suffer from the consequences of the disaster. ${ }^{1}$ It is in precisely this sort of event that we must look for apocalyptic and messianic hopes, since the suffering of the people was such that they had no other place to turn. Therefore, this paper will examine the Muslim apocalyptic responses to this unparalleled disaster, both in the literary realm and how Muslims acted towards their conquerors.

Given the nature of Muslim historiography, of which apocalyptic traditions are a part, the Mongol invasions must be given a place in the framework of the

1 See Ibn al-Athir, Ta'rikh (ed. Tornberg, Leyden: E.J.Brill, 1851-76) xii, pp. 358-59 (quoted in al-Dhahabi, Ta'rikh al-Islam [Beirut: Dar al-Fikr, 1982], lxii, p. 36), who says that there has never been a slaughter like it; also pseudo-Ibn al-Fuwati, al-Hawadith aljamia (Beirut: Dar al-Gharb al-Islami, 1997), p. 109 f.; Ibn Abi al-Hadid, Sharh Nahj al-balagha (Beirut: Dar al-Jil, 1987), viii, pp. 218-43; and Ibn Taghribirdi, al-Nujum al-zahira (Cairo, 1949), vi, p. 277; Abu al-Fida', al-Mukhtasar fi akbbar al-bashar (Beirut: Muhammad 'Ali Baydun, 1997), ii, pp. 302-3; and see J. de Somogyi, "adhDhahabi's Ta'rikh al-Islam as an authority on the Mongol invasion of the Caliphate," Journal of the Royal Asiatic Society 1936, pp. 595-604; idem, "A qasida on the destruction of Baghdad by the Mongols," Bulletin of the School of Oriental and African Studies 7 (1933), pp. 40-48; idem, "al-Dhahabi's record of the destruction of Damascus," in S. Lowinger and J. de Somogyi (eds.), Ignace Goldziher Memorial Volume (Budapest, 1948), i, pp. 353-360; J. Boyle, "The Death of the Last 'Abbasid Caliph," Journal of Semitic Studies 6 (1961), pp. 145-61; and Muhammad al-Faruque, "The Mongol Conquest of Baghdad," Islamic Quarterly 32 (1988), pp. 194-206. 
tradition. ${ }^{2}$ It is not possible to expect that Muslim historians, or religious figures (oftentimes the same people), could ignore this event, or work to make such that it is given an explicable place in the future. ${ }^{3}$ In short, despite the fact that no one foresaw the Mongol invasions on the basis of the existing apocalyptic material, it would be inconceivable for the Muslim that the Prophet Muhammad and the Companions (sahaba) did not hint at it in some way or another in the voluminous tradition material (hadith). Indeed, with an event of this magnitude, Quranic material was sought (and found) to explain it. Even though at this late date, according to the hijri calendar, prophecies could not be forged, they could be reworked or heavily reinterpreted. ${ }^{4}$ This process took several different aspects. Muslim apocalyptic tradition is divided up into a number of cycles of saga, of which two are relevant to this topic. The first is the cycle concerning the Turks, and the second is the Quranic material about Yajuj and Majuj (Gog and Magog). ${ }^{5}$ Both of these topics are intimately concerned with the fear of the peoples of Transoxiania and Persia that the nomadic peoples of the Eurasian steppe would attack and inundate their lands-exactly as it occurred during the years $1220-1450$. Therefore it is only natural that these invasions would be interpreted in the light of those traditions. While there had been earlier invasions of nomadic peoples, these events were not seen in such absolute terms as had to be reflected in the apocalyptic books. In other words, the earlier events were not so bad that they left much of a trace upon apocalyptic works. The Mongol invasions were sufficiently serious that they could not be avoided in the later materials.

Apocalyptic writers were the ones most affected by the reinterpretation process (of hadiths), but both historians and Quranic commentators were compelled to deal with the subject. Whereas for earlier periods of writing in Islam, historians had occasionally mentioned the need to write because the end

2 In other frameworks as well: see the Christian apocalypse on the Mongol conquest J. Ziadeh (ed.), "Une testament de Notre Sauveur concernant les invasions des Mongols," Revue de l'Orient Chrétien 21 (1918-19), pp. 261-67, 433-39; and E. Kennedy (ed. and trans.), "An Astrological History Based on the Career of Genghis Khan," in Quest for Understanding: Arabic and Islamic Studies in memory of Malcolm Kerr (Beirut: American University of Beirut, 1991), pp. 223-31. For Christian historical apocalyptic about the Mongols, see Kirakos Gandzakat, History of the Armenians (trans. Robert Bedrossian, Sources for the Armenian Tradition, New York, 1986), pp. 193-94.

3 Ibn al-Athir, Ta'rikh xii, p. 359 says: "[after comparing the Mongols to Yajuj and Majuj] as for the Dajjal [the Muslim Antichrist], he leaves alive those who follow him, and causes to perish those who oppose him, while those [the Mongols] did not leave anyone - nay, they killed the women, the men and the children, cutting open the stomachs of the pregnant women and killing the foetus..."

4 Earlier apocalyptic events frequently caused the whole scale manufacture of apocalyptic traditions to explain them ex post facto.

5 Taken originally from the material in Ezekiel 38 and Revelation 19. 
of the world was closing in, in the wake of the Mongol invasions there was a general feeling that the end of the world was nigh. This led to a prevalence of historical writing from this particular time by historians who stated specifically that the time before the Day of Judgment was short.

\section{Mongol Invasion: The First Round}

The first round of Mongol invasions descended upon Transoxiana and the easternmost sections of the empire of the Khwarazmshah (1219-21) and turned the entire area of Central Asia into a Mongol province. Ghenghis Khan took vengeance upon this ruler for the treacherous murder of a caravan of merchants (who were possibly spies) in 1218, and visited the worst of the Mongol wrath upon this hapless region. It is significant to note that immediately previous to this invasion there was a series of comets (Jan. 20, 1220 and Feb. 6, 1220), ${ }^{6}$ which undoubtedly aided in creating the apocalyptic atmosphere. Both the historians Ibn al-Athir (d. 1232) and al-Dhahabi (d. 1347) felt this atmosphere; the latter even went so far as to characterize the battles between the Mongols and the Muslims as malahim (apocalyptic wars of the end time). ${ }^{7}$

This apocalyptic atmosphere was further exacerbated by the appearance of Halley's Comet on Sept. 29, 1222, just as Ghenghis Khan was advancing towards Central Asia:

"On 20 Sha'ban [Sept. 30] a star appeared in the sky in the east. It was big and had long, thick locks of hair. It rose with the dawn and stayed like that ten days and then it appeared in the first part of the night in the west, the north-west. All the night it would progress towards the south, about twenty degrees $(\text { dhira })^{2}$ ), according to what the eye saw. It continued closing towards the south until it became truly in the west. Then it went westward tending towards the south after being in the north-west. It stayed like that until the end of the month of Ramadan [end of November] of that year and then disappeared."

These types of astronomical observations were common during this period, and often heralded events that led to the appearance of messianic or apocalyptic transformative movements. ${ }^{\text {? }}$

6 Ho Peng Yoke, "Ancient and medieval observations of comets and novae in Chinese sources," Vistas in Astronomy 5 (1962), p. 191 (nos. 422-23); and Gary Kronk, Cometography, vol. I: Ancient until 1799 (Cambridge: Cambridge University Press, 1999), pp. $208-9$.

7 al-Dhahabi, Siyar, xxii, pp. 243-44.

8 Ibn al-Athir, Kamil, xii, p. 412; and Kronk, Cometography, pp. 209-13 (I P 1222 RI).

9 See my "Messianism and Astronomical Events during the First Four Centuries of Islam," Revue des mondes musulmans et de la Méditerranée 91-94 (2000), pp. 29-52. 
III. Muslim Response: Messianism, the Early Stages

During any times of tension or unrest messianic and apocalyptic movements are likely to come to the fore. They represent the populaces' need to deal with a situation which the authorities are incapable or unwilling to confront. The situation during the early Mongol conquests in Transoxiania was clearly of this nature. Because of the widespread hatred for the Mongols (as a result of the fact that the latter were non-Muslims) the situation in Central Asia was ripe for a popular rising. The elites could no more defend the people against the Mongol invaders than they could against a natural disaster, and more than frequently collaborated with them anyway. After some 20 years of Mongol rule, the hatred of the populace was such that their feelings were ready to be expressed through revolt. According to one account, that of (pseudo-) Ibn al-Fuwati (d. 1323?), during the year 1240 one such messianic movement appeared in Transoxiania:

"In it [the year] a non-Arab Sufi man appeared in Bukhara, who was known as Abu al-Karm al-Darani, and would show the people wondrous [feats] of juggling, ${ }^{10}$ and he would order a man to fire an arrow at him, and he would be unable to, so he grew proud and was nicknamed the Mahdi. He ordered the killing of Christians and Jews in Bukhara, and the theft of their possessions, and they were killed and dispossessed. He said to his followers: I am able to kill the Mongols, and to break them by myself, and those that follow me, by the power of God without needing weapons. Many followed him, and rose up against the garrison of Bukhara, and the armies with them, and killed them. After that, a great number joined him, and Jurmaghun was informed of him, and he grew angry (the matter seemed great to him) and he sent an army and a garrison to Bukhara. Abu al-Karm went out at the head of many thousands, and he commanded them to accompany him without arms. The Mongols drew back when they met them [in battle] and then one of their commanders came forward, and said: 'I would like to try, whether I kill him, whereupon the army [can] advance and kill every last one of them, or whether I perish like they claim.' Then he attacked Abu al-Karm and killed him, and then the armies busied themselves with them [the people] and killed them, and hardly any of them escaped. It is said that their number was 60,000."11

On the face of it, this messianic movement follows a classic pattern. There is the appearance of the holy man, and the process by which he establishes himself. $\mathrm{He}$ makes claims (or in this case apparently claims were made for him), and the validity of those claims are based on actions whose interpretation he manipulates. This leads inevitably to real struggle against a powerful foe, and

10 See on this typos: Stefan Wild, "Jugglers and fraudulent Sufis," in Proceedings of the $V I^{\text {th }}$ Congress of Arabic and Islamic Studies, Visby 13-16 August, Stockholm 17-19 August 1972. Leiden: E.J. Brill, 1975, pp. 58-63.

11 (pseudo-) Ibn al-Fuwati, Hawadith, pp. 127-28; first noted by A. Tritton, "False prophets and others," Journal of the Royal Asiatic Society 1957, p. 3; and see also al-Sibt Ibn al-Jawzi, Mirat al-zaman (Haydarabad: Dar al-Ma'arif, 1951), viii, p. 660. 
since the messianic claimant was apparently victorious (albeit temporarily), his claims were further confirmed. However, key truths were not noted during the confirmation process: i.e., that the victory over the Mongols of Bukhara was not accomplished entirely without the use of weapons as the messianic claimant had stated. Most likely it was accomplished through "people power" - the sheer weight of the mass of people attacking the hated overlords. After this surge of popular feeling the larger world intervened in the fantasy, in this case in the form of the Mongol commander, Jurmaghun. He, however, was still part of the dramatic fantasy, since he believed in the power of the messianic claimant as well, or at least was wary of his apparent abilities. Quickly, however, the emperor was exposed in his new clothes, when one of the soldiers decided to sacrifice himself for the sake of the greater Mongol army. This sacrifice popped the balloon and the fantasy disappeared into grim reality in the form of Mongol vengeance for being taken in by the impostor.

This is not, however, the only account of this incident, nor is it necessarily the most accurate. Another far more likely account from the later historian Khwandamir (d. 1535?) reads as follows:

"In the year 630 [1232-33] in the village of Tarab, three leagues from Bukhara, a person named Mahmud began a career of deception and imposture by pretending to be a pious ascetic and claiming that he met with djinn, ${ }^{12}$ who informed him of hidden things, By listening to such nonsense, a large number of ignorant and common people became Tarabi's devotees. Some sought healing from him, and as chance would have it, several people were actually cured, and this resulted in an increase in the people's belief in him, and large numbers of people began to come from all parts. One of the learned of Bukhara, Shamsuddin Mahbubi by name, because of the fanatical hatred he harbored toward the elite and noble of Bukhara, became a disciple of the ignorant Tarabi, saying: 'My father wrote in one of his works that a blessed man of a certain description would emerge from Tarab in Bukhara and conquer the world. That description fits you.' Hearing this, Mahmud's conceit grew until he began to covet being king. Some of the Mongol amirs who lived in Bukhara, concerned about him, went in a group to Tarabi, showing him respect and homage, and said: 'It would be best for the shaykh to come into the city so that the people there may benefit from your presence.' Tarabi granted this request and set out for the city."13

This account of the beginning of this movement is far more plausible than that related by (pseudo-) Ibn al-Fuwati. It is likely that he relates the correct name of the messianic claimant, Mahmud Tarabi, of which the nisba (name affiliation

12 Spirits of fire mentioned in the Qur'an (e.g., 7:38, 51:56), cf. Encyclopedia of Islam ${ }^{2}$ (Leiden: E.J. Brill, 1960-2000), sv. “djinn” (D.B. MacDonald-H. Massé).

13 Khwandamir, Habib al-siyar (trans. W. Thackston, Sources of Oriental Languages and Literatures 24, Harvard, 1994), iii, pp. 44-45. 
with a city or territory) was reduced in Ibn al-Fuwati to "al-Dirani." Khwandamir's account presents Tarabi as a puppet in the hands of a much more intelligent and dangerous character, who basically manipulates the action. We also see that this messianic revolt is directed against the elites of Bukhara who are in collaboration with the Mongol government. Incidentally, there was a comet prominent in the sky just previous to Tarabi's appearance. ${ }^{15}$

"The darugha" and nobles of Bukhara had decided beforehand that when he reached the bridge he would have to cross, they would kill him. The fraudulent shaykh, however, learned of this plot, and after reaching the spot he said to the darugha: 'Call off your insidious plot, or else I, without the intervention of human hand, will cause your eyeballs to fall out of their sockets.' The amirs, greatly concerned by the revelation of their plot, did not bother Mahmud, who entered Bukhara and settled in a suitable house. The crowds that flocked to him grew so pressing that not even the wind could blow through. The darugha and amirs waited for an opportunity to get rid of the fraudulent shaykh, but because of the crowds of people coming and going they had no chance at him."17

Here we see some of the basis of the messianic claimant's spiritual authority. His knowledge enables him to defeat those enemies seeking to kill him, and become a symbol of the anti-Mongol resistance.

"Around that time one of the shaykh's disciples learned of the amirs' plot, and Tarabi left through a hidden door, mounted a horse, and rode as fast as he could to Bahafs Hill. When the common people of Bukhara saw the khawaja [master] there, they began to riot, saying: 'The khawaja has flown from his house and reached Bahafs Hill in the twinkling of an eye!' Thereupon, high and low alike, beside themselves, joined Tarabi, who addressed the people that night, saying: 'Aspirants, how long can you ignore God? The face of the earth must be cleansed of the existence of the filthy infidels, and the true religion must be spread.' Receiving this blanket permission from the shaykh, the ignorant and common people took up arms and rushed in Mahmud's wake into the city. The darugha and Mongol amirs fled, and Tarabi entered Bukhara in great pomp and circumstance. On Friday he had the khutba read in his own name, and anyone he feared he had exiled. He gave the ruffians and hoodlums free rein to enter the houses of the rich and take whatever they wanted."18

While Khwandamir mentions nothing of Mahmud Tarabi's messianic titles it is clear that he must have had them or at least close to this type of authority:

14 See Yaqut al-Hamawi, Mujam al-buldan (Leipzig, 1924), i, pp. 833-34 for Turban close to Samarqand; and see al-Sam'ani, Kitab al-ansab (Haydarabad, 1963), iii, pp. 30 32 (no. 699); and Ibn al-Athir, al-Lubab fi tahdhib al-ansab (Beirut: Dar Sadir, n.d.), i, p. 210 (who prefer "Turabi”).

15 Ibn Dawadari, Kanz al-ghurar (Cairo: al-Khanji, 1960), vii, p. 310 (dated probably to June-July 1233); this should probably be compared to the comet of Oct. 17-Dec. 14, 1232: see Kronk, Cometography, p. 215.

16 Mongol military leadership.

17 Khwandamir, Habib al-siyar, iii, p. 45.

18 Khwandamir, Habib al-siyar, iii, p. 45. 
"Around that time he happened to say, 'Soon arms will come to us from the unseen world.' By chance, soon after that, a group of merchants from Shiraz displayed their merchandise in Bukhara - four loads of swords. This occurrence further strengthened the people's belief, and after Mahmud had reigned for several days the darugha and amirs who had left Bukhara returned with a large army ready to do battle. Tarabi commanded that they be met, and when he was near the Mongols he arrayed his troops and stood himself, along with Shamsuddin Mahbubi, in the center. Since word had spread among the people that, in addition to physical troops, Tarabi had an army of djinn flying between the earth and the sky, and that the hand of anyone who drew a sword or shot an arrow at him would shrivel, the Mongols drew their bows and arrows in fear and trembling. Finally two lethal arrows shot by destiny hit Mahmud Tarabi's and Mahbubi's mortal spots, and they fell dead, but there was so much wind and dust stirred up by the battle that no one realized it. Chagatai Khan's men attributed the storm to the shaykh's miraculous powers and took flight. The shaykh's disciples pursued them, killing nearly ten thousand of them, but when they returned to their camp and could not find Tarabi alive, they said: The khawaja has gone into occultation. They placed his brothers Muhammad and Ali on the throne and pledged their allegiance to them."

"When the news reached Amir Qarachar, he appointed two brave noyans to take a huge army and deal with the rebellion. They reached Bukhara one week after Tarabi was killed, and Tarabi's brothers arrayed their troops against the Mongols and fought a fierce battle in which nearly twenty thousand were killed on both sides. Tarabi's brothers were brought down and the devotees crept away into crevices and holes. The Mongols, imagining they would massacre the inhabitants of Bukhara and plunder the town, set out for the city..." [which they did not do, since the Mongol commander Amir Qarachar forbade them from doing it ${ }^{19}$

Thus, at least according to this account, the foolish Bukharans were saved from the consequences of their actions.

At the same time the messianic atmosphere was being realized in the area of Anatolia, where a prophet named Baba appeared about the same time as did Mahmud Tarabi (in 638/1240): ${ }^{20}$ "During it there appeared a Turkman in [Seljuq] Rum (Anatolia), who was called Baba, and who claimed prophecy and said: 'There is no God but Allah and Baba is the friend (wali) of God.' A large number of people gathered to him, and the lord of [Seljuq] Rum sent an army, and they met (in battle), and 4000 were killed among them, among them the aforementioned Baba." ${ }^{21}$ Although little is known about this revolt, it is important in history because the Baba mentioned, Baba Ilyas, is one of the founding fathers of the Sufi Bektashi order. ${ }^{22}$ Baba Ilyas according to the early

19 Khwandamir, Habib al-siyar, iii, p. 45.

20 Note that previous to his appearance there was a guest star (probably a comet) on Aug. 17, 1240: Kronk, Cometography, pp. 215-7 (C/1240 BI).

21 Ibn Taghribirdi, al-Nujum al-zahira, vi, p. 339; al-Sibt b. al-Jawzi, Mir'at al-zaman, viii, p. 733; al-Maqrizi, al-Suluk li-ma'rifat al-duwal wa-l-muluk, i, p. 307.

22 See Ahmed Karamustafa, "Early Sufism in Anatolia," in Leonard Lewisohn (ed), The Heritage of Sufism (Oxford: OneWorld Press, 1999), i, pp. 175-98, at p. 179-80; also 
Turkish hagiography of Elvan Çelebi (d. ca. $14^{\text {th }}$ cen.) ascended into heaven on a white horse, and his followers continue to expect him as a messianic figure. ${ }^{23}$

A certain figure called Dawit the deceiver was also active in Armenia during these years. He appeared in the year $1250,{ }^{24}$ and proclaimed a messianic healing ministry. It was not long before he had gathered huge crowds and even gained the allegiance of a number of clerics. Although we are not informed of any political message which proclaimed, it is clear that his movement was a massive one and probably had some political overtones. In the end, after a few setbacks, the clerics of Armenia managed to overcome his movement and took an oath from him that he foreswore his previous activities. ${ }^{25}$

It cannot be a coincidence that all three of these territories had felt the harsh hand of the Mongols during the first lightning campaign of the Ghenghis Khan in 1219-21, and were still reeling from this destruction. Messianism was one response to the difficulties from which they were suffering. Although none of the movements had overt political overtones, all of these movements are ultimately directed against the political elites, which were discredited through their military defeat by the Mongols. While the Anatolians and the Armenians managed to suppress the messianic movements, it is not surprising to find that the elites of Transoxiana were too crushed to be very effective against the movement of Mahmud Tarabi.

\section{Perceptions: The Fulfillment of Prophecy}

Another response was the fulfillment of prophecy. Apocalyptic and messianic movements cannot be understood without feeling the atmosphere which would have been felt by the population at the time. This necessitates a thorough study in the case of apocalyptic of the relevant passages of the hadith literature.

John Birge, The Bektashi Order of Dervishes (London: Luzac, 1965), pp. 45-6; and Encyclopedia Iranica (London: Routledge \& KeganPaul, 1982-), sv. "Bektašiyya” (Hamid Algar).

23 Elvan Çelebi, Menakibu'l Kudsiyye fi menaibil unsiyye (Istanbul: Edebiyat Fakultesi Matbaasi, 1984), pp. 44-60, 65 (thanks to Betul Cavdar for help in translating these passages).

24 One should note the appearance of a major meteor shower during that year: Umberto Dall'Olmo, "Meteors during the Middle Ages," Journal for the History of Astronomy 9 (1978), p. 131.

25 Kirkos Gandzaket, History of the Armenians, pp. 270-77. 
a. The fulfillment of the Turkish prophecies

Although the primary enemies of the Muslims in apocalyptic perceptions have always been the Christians, most specifically the Byzantine Christians, ${ }^{26}$ the Turks were not entirely ignored. Traditions concerning the Turks are to be found in the earliest collections, usually defined by pejorative physical characteristics. $^{27}$

"The Hour will not arrive until you (the Muslims) fight a group with small eyes, wide faces, as if their eyes were the pupils of locust, as if their faces were beaten shields, wearing shoes made of hair, taking up leather shields until they fasten their horses on a palm tree [in Iraq]. ${ }^{.28}$

The anti-Turkish traditions had a wide circulation in early Islam, especially after the beginning of large-scale Turkish slave imports during the $9^{\text {th }}$ and $10^{\text {th }}$ centuries. Some of this animus died down (at least among Sunnis) during the $11^{\text {th }}$ and $12^{\text {th }}$ centuries when the Seljuq dynasty was seen by many as the defender of the sunna. However, the anti-Turkish material was never excised from the books of apocalyptic prophecies and remained, together with the materials about Gog and Magog (in the Quran 18:94, 21:96, yajuj wa-majuj) as a promise that God would send punishment upon the Muslim community from this source.

Other prophecies were to be found which were obviously manufactured for the appearance of the Mongols. For example, in the Tabaqat-i Nasiri of Juzjani (d. 1259), one such is cited:

"A tradition to this effect had been handed down by the ancients that when the outbreak of the Turks should arise and the narrow-eyed should seize upon the universe, and they should devastate the countries of 'Ajam and the kingdoms of Iran, whenever an army of them should reach Lohore, the dominion of that race would begin to decline and the power of the infidels would diminish... Jamal alDin al-Bustaji used to say: 'Oh God! Speedily transport a Mughal army to Lohor [Lahore] that they might reach it?"'29

It is by no means exactly clear what the point to this tradition is. But it is interesting that as Juzjani died shortly after the Mongol conquest of Baghdad, when the Mongols had been known in the Muslim world for at least 40 years,

26 See my Studies in Muslim Apocalyptic (Princeton: Darwin Press, 2002), chapter 1.

27 Ibid, pp. 84-91; there was another side to the coin - see I. Goldziher, Muslim Studies (trans. S. Stern and C Barber, London, 1971), i, pp. 245-6 for positive traditions about Turks; also al-Jahiz, Rasa'il al-Jahiz (Beirut: Dar al-Kutub al-Tlmiyya, 2000), iii, pp. $125-68$.

28 al-Hindi, xiv, p. 206 (no. 38407).

29 Minhaj al-Din Juzjani, Tabaqat-i Nasiri (trans. H. Raverty, New Delhi, Oriental Reprints, 1970), ii, pp. 1136-39, 1142 (= Tabaqat-i Nasiri [ed. A. Habibi, Kabul, 1964-65]), ii, p. 643. 
there was still a close identification between them and the Turks. The two terms were used in this selection interchangeably. Other non-Muslims, such as the Armenians, also characterized the Mongol invasions as "this is the end of time; and precursors have spoken about the antichrist and the arrival of the sons of destruction" ${ }^{\prime 30}$ and cited prophecies of a Christian origin to place them within an explicable context. However, political events are not the only prophecies that were fulfilled during the Mongol invasions.

b. The apocalyptic scare at Medina in 1256

One of the physical signs of the end of time is the appearance of fire in the Hijaz near Medina, probably based on the real recollection of a volcanic eruption at the time of the Prophet or more likely during the time of the first century of Islam. Medina is surrounded on three sides by lava flows and so volcanic activity is hardly unknown. Some of these traditions deserve to be quoted to obtain the general tenor of them: "The Hour [of Judgment] will not come until fire will issue forth from the land of the Hijaz lighting up the necks of the camels in Busra [Transjordan]." "The Hour will not come until fire will issue forth from a wadi - and he mentioned its name - of the wadis of Banu Sulaym in the Hijaz lighting up from it the necks of the camels in Busra." ${ }^{32}$ A number of other locations are mentioned connected to this fire: Hadramawt, ${ }^{33}$ the Sea of Hadramawt, ${ }^{34}$ Barhut, ${ }^{35}$ Habs Sayl, ${ }^{36}$ and Jabal al-Warraq (in the Yemen). ${ }^{37}$

30 Gandzakat, History of the Armenians, pp. 193-94 (he concludes by saying that St. Nerses had predicted the destruction of Armenia by "the Nation of the Archers... which we have witnessed with our own eyes.").

31 al-Bukhari, Sahih (ed. 'Abdallah b. Baz, Beirut: Dar al-Fikr, 1991), viii, p. 128 (no. 7118); al-Hindi, Kanz al-'ummal (Beirut: Mu'sassat al-Risala, 1989), xiv, p. 344 (no. 38883); other traditions dealing with this can be found in Ibn Hibban, Absan altartib bi-Sahih Ibn Hibban (Beirut: Dar al-Fikr, 1987), viii, p. 297; Ibn 'Adi al-Jurjani, al-Kamil fi du'afa' al-rijal (Beirut: Dar al-Fikr, 1988), v, p. 163; Ibn Ta'us, al-Fitan wa-lmalahim (Beirut: Mu’assasat al-A'la li-l-Matbu'at, 1988), p. 144; Ibn Hajar al-'Asqalani, Lisan al-mizan (Beirut: Dar al-Fikr, 1987), IV, p. 355; al-Suyuti, al-Durr al-manthur (Cairo: al-Anwar al-Muhammadiyya, n.d.), vi, pp. 61, 67.

32 al-Dani, al-Sunan al-warida fi al-fitan wa-ghawa'iliha wa-l-sa'a wa-ashratiha (Riyad: Dar al-Asima, 1995), iii, p. 995 (no. 531); Ibn Tawus, Malahim wa-l-fitan, p. 88-89.

33 al-Hindi, Kanz al-ummal, xiv, p. 345 (nos. 38884-85).

34 Ibn Abi Shayba, Musannaf (Beirut: Dar al-Fikr, 1989), vii, p. 471 (no. 37320).

35 al-Hindi, Kanz al-ummal, xiv, p. 345 (no. 38886).

36 al-Hindi, Kanz al-ummal, xiv, pp. 346-47 (nos. 38889, 38891).

37 Ibn Abi Shayba, Musannaf, vii, p. 471 (nos. 37315, 37319); al-Hindi, Kanz al-ummal, xiv, pp. 347-48 (nos. 38892, 38895). During 1255 there was in fact a volcanic irruption in 'Adan: Ibn al-Imad, Shadharat al-dhahab (Damascus: Dar Ibn Kathir, 1995) vii, p. 440; and Ibn al-Sabat, Ta'rikh (Tripoli: Jurus Bris, 1993), i, p. 364 which only added to the general feeing that prophecy was being fulfilled. 
In an atmosphere as charged as that of the 1250s, when the Mongols threatened the heartland of the Muslim world, and a number of apocalyptic events had already occurred (according to the perception), it would be irrational to expect people to concern themselves with probabilities, or facts; the immediacy of the end would be too apparent for such thoughts to occur. Thus, it is hardly surprising that when there actually was an event similar to that predicted in the Prophetic traditions during this time, an apocalyptic hysteria in the city of Medina was the result. This is recorded in several different accounts.

"In [the month of] Jumada al-Akhira there were frightening earthquakes in the outskirts of Medina, such that the noble minbar [the pulpit] swerved and the chains of the lanterns moved. Then in Rajab fire appeared at a distance of four parsecs from [Medina] continuing 25 days. This would eat the stones...the people entered into the haram [the Prophet's Mosque] and beseeched God and repented and the ruler of Medina freed his slaves, and expedited with all the complaints (mazalim), and returned all the lands seized from their rightful owners. Then it was put out by the power of God." 38

Other sources portray the event slightly differently:

"During this year...on Wednesday night, the 3rd of Jumada al-Ukhra year [6]54 [1256-57] a great sound/noise occurred followed by an immense earthquake, which shook the city: the walls, the roofs, and the wood (akhshab) [beams, or supports] hour after hour until Friday, the 5th of the aforementioned month, [when] a great fire [lava] appeared in the Harra, close to Qurayza-we could see it from our courts from inside Medina as if it was right in front of us. This was a great fire, blazing up, and the wadis were flowing with fire because of it to Wadi Shata the confluence of the flow." ${ }^{39}$

This was only the beginning for the unfortunate people of Medina. During this period a series of earthquakes, 14 in all, struck the area, and the lava flowed around the city, cutting off the city from the pilgrims route to Iraq (which passed right through the lava fields to the east of the city), and making life unbearable. As noted above, the response of the denizens of the city was clear:

" $\mathrm{I}^{40}$ went to the amir, and spoke to him, saying: 'Punishment ('adhab) has surrounded us ${ }^{41}$ - return to God!!' and so he freed his slaves (mamalik), and

38 (pseudo-) Ibn al-Fuwati, Hawadith, pp. 315-16; also al-Suyuti, History of the Caliphs (trans. Henry Sullivan Jarrett, Oriental Press: Amsterdam, 1970), p. 492; and see S. Bashear, "Muslim apocalypses," Israel Oriental Studies 13 (1993), p. 98, note 116.

39 al-Yunini, Dhayl mira'at al-zaman (Haydarabad: Dar al-Ma'arif, 1955), i, pp. 4-5; see also al-Yafii, Mira'at al-jinan (Haydarabad: Dar al-Ma'arif, 1919-20), iv, p. 131-32 (who mentions the apocalyptic prophecies); Ibn al-Imad, Shadharat al-dhahab, vii, p. 454.

40 Shams al-Din Sinan b. 'Abd al-Wahhab b. Numayla al-Husayni, the qadi of Medina, who wrote one of the letters upon which the historians based their accounts of these incidents.

41 A paraphrase of several Quranic verses 
returned to the people their possessions. When he did this, I said to him: 'Descend this very hour to the Prophet['s gravesite in the Mosque] together with us', and he descended and we spent Saturday night, the whole people and the women and their children - none remained in al-Nakhil [the date palm groves] nor in the city-all were with the Prophet..."

Other sources say specifically that the people of Medina thought this was the Day of Resurrection (zanna ahl al-Madina innaha al-qiyama)..$^{43}$ One can easily see that in this situation, the focus of power within the city changes abruptly. The governor no longer is the person giving the orders - he is given orders by the qadi, whom one would assume from the tone of the letter has tried to give instructions to him before and has failed. At this moment, however, the situation is out of the governor's control, and he listens to the previously ignored qadi, and gives the people justice and frees his slaves. This last is a rather interesting element, since it is closely related to another apocalypse in which the response of the people to earthquakes is to free the slaves. ${ }^{44}$

Shortly thereafter two more disasters occurred: there were eclipses of the sun and the moon (possibly because of the ash of the volcanic eruptions), and the there was a serious fire in the Prophet's mosque. ${ }^{45}$ The conjunction of eclipses of both the sun and the moon during the course of one month is held to be one of the signs of the end. ${ }^{46}$ Without a doubt these events, occurring just a year and a half before the destruction of Baghdad by the Mongols heavily influenced the apocalyptic atmosphere.

\section{Mongol Reaction: The Destruction of Baghdad}

The Mongols were not slow to fulfill the Muslims' worst fears of their own apocalyptic destruction. Their second thrust into the Muslim world began when Hulegu, the brother of the Mongol Khan Mongke, set out to punish the Ismaili Assassins (who had previously threatened the khan) located in northern Persia during 1253. This operation was finished by 1256, and Hulegu turned his attention to the caliph in Baghdad, who should have been properly submissive. It was impossible for the 'Abbasid caliph al-Mutasim (1255-8) to submit to an unbeliever such as the Mongol Hulegu, and this fact set off a chain of events that culminated in the caliph's murder and the end of the 'Abbasid caliphate. Of

42 al-Yunini, Dhayl mira'at al-zaman, i, pp. 6-7; and further on pp. 8-10.

43 al-Yafici, Mira'at al-jinan, iv, p. 132.

44 See Studies in Muslim Apocalyptic, Appendix I, no. 15.

45 al-Yunini, Dhayl mira'at al-zaman, i, p. 10; (pseudo-) Ibn al-Fuwati, Hawadith, p. 305; and Ibn al-Sabat, Ta'rikh, i, p. 373.

46 E.g., Studies in Muslim Apocalyptic, p. 371. 
course, it goes without saying that such an event could not have gone without being heralded by celestial events, which took place during 1258 .

"We were facing towards the west, and we saw a great sign, and this was the appearance of light in the west before the later nightfall (al-isha al-akhira) like the light of the sun before its rising. The people were terrified, and then it went and the darkness of night returned, and I slept that night and I saw in the manner of a sleeper a man who said to me: 'Do you know what the meaning of that light is?' I said 'No.' He said 'That was a gate into the heavens, which has not been opened since God created the world other than tonight, and that is the gate of mercy, which He opened for the people." ${ }^{\prime 7}$

It is said that when the Mongols killed al-Mustasim a star disappeared from the heavens, and did not reappear until the new 'Abbasid claimant al-Hakim was enthroned in Cairo by the Mamluks. ${ }^{48}$ Perhaps this explains the attitude of an astronomer named Husam al-Din, who is said to have told Hulegu that if the caliph al-Musta'sim was killed, then the world would darken and the signs of doomsday would appear. Unfortunately for Husam al-Din, Nasir al-Din al-Tusi, the famous astronomer, was also consulted, and he pointed out the obvious weaknesses in the man's argument. Hulegu took the compromise route: if when the caliph was killed the things which Husam al-Din had warned about actually happened then he would live; if not, then he would die. ${ }^{49}$ Husam al-Din was executed shortly thereafter. ${ }^{50}$

\section{Muslim Response: Literary Apocalypticism}

\section{a. Apocalyptic texts}

During the years immediately following the Mongol destruction of Baghdad and the eastern part of the Muslim world, there was a great upsurge in the writing of apocalyptic books and pamphlets. Without a doubt, it is to this unprecedented amount of writing on the subject that we owe the survival of so much of the apocalyptic heritage of Islam, which had probably been at least damaged to some extent by that destruction. However, these apocalyptists take a number of different approaches. While all felt that the destruction was awesome and apocalyptic in significance, some were able to rejoice in it (even those who

47 Ibn al-Qasim, Ghayat al-amani fi akhbar al-qatar al-yamani (Cairo: Dar al-Katib al'Arabi, n.d.), i, p. 445.

48 al-Mufaddal b. Abi al-Fada'il, History of the Mamluk Sultans in Patrologia Orientalis xii, pp. 434-35.

49 Khwandamir, Habib al-siyar, iii, pp. 60-61.

50 See Boyle, "The Death of the Last 'Abbasid Caliph", Journal of Semitic Studies 6 (1961), pp. $145-61$. 
hated the Mongols) because they desired the end of the world to come, and were happy that Islam was rid of so much of its material culture and could thus be freed for purely spiritual pursuits. This is a minority approach, but it is to be found (see below). Others rejoiced because their apocalyptic scenarios required the demise of the Sunni caliphal state, and felt that future redemption was close. These were mainly Shicites. However, for the vast majority of Sunni apocalyptists, the Mongol destruction was an unmitigated and unparalleled disaster and they make no effort to hide their dismay. This attitude is felt right across the Mediterranean from Egypt, where the Mongol menace was a clear and present danger, to Andalus (Muslim Spain), where they were not clearly known, but still feared by the population to some extent.

Two major writers, the Shicite Ibn Ta'us (d. 1266), who wrote his al-Fitan wa-l-malahim in the years 1260-62, and the Sunni al-Sulami (d. 1261), wrote in the immediate wake of the Mongol conquest of Persia and Iraq. ${ }^{51}$ While it is clear that both of them saw this as an apocalyptic event, the Shicite Ibn Ta'us does not mention negative traditions about the Turks. Al-Sulami, on the other hand, revived a considerable number of traditions concerning the Turks, and even cites one unique one (not previously attested) that seems to indicate that the Turks (perhaps the Mongols in this case) were acting in accord with God's will:

"God most high says: 'When My servants have disgraced My sanctity, declared lawful the things prohibited by Me, [and] broken My commandments, then I gave them into the hands of an army from the east called the Turks. They are My horsemen, and take vengeance on those who rebel against Me. I have removed mercy from their hearts: they take no pity on those who weep, and do not answer those who complain, killing the fathers and the mothers, the sons and the daughters'..."

This is a strong tradition and if it were to be related to the situation of the Mongol conquest of the eastern part of the Muslim world, would indicate that some Muslims (perhaps) saw the Mongols as God-ordained. If that were true, it would be fairly unique within the context of Muslim apocalyptic beliefs.

Many other apocalyptic writers mention the Turks (or Gog and Magog) as the Mongols. Starting with the Spanish writer al-Qurtubi (d. 1272) this became a common theme in apocalyptic writing. Al-Qurtubi devotes a number of pages to the question of the Turks, above and beyond that which would have been justified for someone living in Spain - so far away from any attacks by the

51 The historian Ibn al-'Adim (d. 1261) in his Bughyat al-talab fi ta'rikh Halab (Beirut: Dar al-Fikr, n.d.) devoted nearly 40 pages of his first volume (pp. 485-525) to apocalyptic traditions, but none mention the Mongols.

52 al-Sulami, 'Tqd al-durar fi akhbar al-muntazar (al-Zarqa': al-Manar, 1987), pp. 117-18 (no. 86). 
Turks. He cites all of the negative traditions about them, and then gives his readers several pages of a description of the Mongol invasions up until his time. He says: "in the year 617 [1220] an army of the Turks called the Tatars appeared..." 33 and then relates all the historical events up until the defeat of the Mongol army at 'Ayn Jalut (1260) in which the Mongol advance toward Egypt was halted.

Although the prominent historian and exegete Ibn Kathir (d. 1372-3) does not mention the Mongols in his apocalyptic collection, he speaks about the Turks and identifies them with Gog and Magog of the Quran. ${ }^{54}$ However, when he speaks of Gog and Magog later on in the book he identifies them with the Mongols (as he does in his Qur'anic exegesis below). ${ }^{55}$ This conclusion was only popular among the apocalyptic writers for a short time. For example, al-Sakhawi (d. 1496-7) when he discusses the Gog and Magog does not mention the Mongols, but when he discusses the anti-Turk traditions he includes the Mongol invasions inside a list of the times when the Muslims have fought the Turks. ${ }^{56}$ But some such as the $17^{\text {th }}$ century apocalyptic writer al-Barzanji, citing older materials, still do refer to the Turks as "Mongols". ${ }^{57}$ Presumably the difference between these two writers is the fact that for al-Sakhawi the Mongols were no longer a present danger to the Muslim world as two centuries had elapsed since the destruction of Baghdad. But the Turks (in the form of the Ottoman Empire) were a major threat to the Egypt of al-Sakhawi (conquered in fact shortly after his death), and thus he felt free to demonize the Turks. Probably alBarzanji felt just the opposite since he was living under Ottoman Turkish rule, and may have felt the need to protect the Turks to some extent from the antiTurkish animus present in the apocalyptic literature by identifying the enemy with the long-disappeared Mongols.

\section{b. Apocalyptic histories}

Just as with the apocalyptic books, historians were suffused with an apocalyptic interpretation of the Mongol invasions. Several of these have already been quoted (Ibn al-Athir and al-Dhahabi for example). These were not isolated

53 Al-Qurtubi, al-Tadhkira fi ahwal al-mawta wa-l-umur al-akhira (Cairo: Dar al-Zahid alQudsi, n.d.), p. 677.

54 Ibn Kathir, al-Nihaya fi al-fitan wa-l-malahim (Cairo: al-Maktab al-Thaqafi, n.d.), i, pp. 19-20.

55 Ibid, pp. 200-1; he also identifies the fire in Medina (above) with the apocalyptic fire: pp. 26-7; as does al-Barzanji, al-Isha'a li-ashrat al-sa'a (Beirut: Dar al-Hijra, 1995), pp. 63-5.

56 Al-Sakhawi, Ashrat al-sa'a ('Amman: Dar 'Ammar, 1997), pp. 94-5; see also his alQana'a fi ashrat al-sa'a, bound with Izz al-Din 'Abd al-'Aziz al-Sulami, Bayna ahwal alnas yawm al-qiyama (Beirut: Dar al-Kutub al-Tlmiyya, 2003), pp. 67-8, 98-9.

57 Al-Barzanji, Isha'a, p. 58. 
cases. Even in distant Morocco, the word that Yajuj and Majuj were loose arrived and was received with terror. ${ }^{58}$ Quite a number of historians who wrote in the $13^{\text {th }}$ and $14^{\text {th }}$ centuries did so with the obvious sub-text that they were writing histories of the end; they were not world-histories, but histories of the world. ${ }^{59}$

One of the most neglected apocalyptic histories is that of Minhaj al-Din alJuzjani, Tabaqat-i Nasiri, which has been published in a number of editions and translated into English. ${ }^{60}$ In addition to the many apocalyptic prophecies inside the volume (some cited above), there is a qasida (epic poem) that has a good deal of bearing on the feelings of the Muslims at the time. While it would be legitimate to say that this qasida does not reach the highs of classical Arabic composition, it would not be fair to say with Raverty (the English translator) that "as the kasidah itself and our author's commentary thereon, which is very diffuse, are of no historical value whatsoever, and as the former is very similar to others omitted at the beginning of the Section, I see no occasion for burdening the translation with it." ${ }^{61}$ Since apocalyptic feelings are an extremely important and vital expression of feelings and thus of history overall a translation is very much in order:

"Be ware, my son, of the tenth conjunction, and warn your family before the warning of the warner;

Dwell in the land of the Hijaz, and be [continuously] in it, and be patient during the pain of the iniquitous time;

Do not under any circumstances leave for Iraq, for the cutting point of the sword will rip it;

From the tribulation of the flat noses, ${ }^{62}$ as if they were a flood overflowing or like the widespread locust...

They have no intention other than [to shed] blood; vengeance upon them is enjoined upon every forbidder;

Khawarizm will be shown to you as it returns to be a growing place for grass; for its people there are no graves;

58 Ibn Abi Zara', al-Dhakhira al-saniyya fi ta'rikh al-dawla al-Mariniyya (Ribat: Dar alMansur, 1972), p. 58.

59 See, e.g., al-Yunini, Mira'at al-jinan, iv, pp. 132-3.

60 However, the English translation by H.G. Raverty (Tabakat-i Nasiri [New Delhi: Oriental Reprint, 1970]) made in 1881 leaves much to be desired. The translator is extremely hostile and denigrating to the author of the text, whom he regularly characterizes as "ignorant", "stupid" and so forth. He does not translate any of the apocalyptic sections, since he sees them as part of the overall stupidity of the author: "I need scarcely follow him [in translating the apocalyptic sections of the book], since the world has not yet come to an end, although more than six centuries have elapsed since he foretold it..." (ii, p. 869).

61 Raverty, ii, p. $1281-2$.

62 I.e., Mongols. 
Khurasan the same, and Balkh after it, and Herat will be taken after Nishwar is taken;

The land of the Daylamites - its mountains and its fortresses - are destroyed; having not a single inhabitant;

In Rayy, they will kill a group of the family of Muhammad - at the sword of the infidel;

Their king will flee from the shedding of blood like the dove flees from the flesheating eagle...

When half the conjunction is gone, you will see them in the land of creation with a numerous army;

The victorious king will cause them to perish just as Thamud ${ }^{63}$ perished of old. “64

This qasida is very much in the spirit of other dramatic poetry that was composed in the immediate wake of the fall of Baghdad. Al-Juzjani looks for the Mongols to be defeated by a future victorious king, presumably the messianic figure, the mahdi. But it is also clear that he, like so many of the other writers, places the Mongols within the framework of the Turkish tribulations; he does not mention Gog and Magog. Other contemporary historians such as the proShicite Ibn Abi al-Hadid (d. 1258) also describe the Mongol invasions as a Turkish tribulation. In a work that is dedicated to commenting on the works of the early caliph and Shicite figure 'Ali b. Abi Talib (d. 661), in the very last volume after citing the anti-Turkish tradition (above) he gives his readers a lengthy description of the Mongol depredations. ${ }^{65}$ Both al-Juzjani and Ibn Abi al-Hadid, though one was Sunni and the other pro-Shicite, do not actually mention the end of the world specifically, but merely see the Mongol invasions as a test of the believers' faith prior to the end.

Not surprisingly the historian and exegete Ibn Kathir (also an apocalyptic writer) gives us the strongest sense that the end of the world was near. His monumental history, al-Bidaya wa-l-nihaya (The Beginning and the End), which, while written 100 years after the fall of Baghdad to the Mongols, still preserves the idea that the world was close to its end. We have already cited his section on apocalyptic prophecies which appears at the end of his world history, and implies that the end was sufficiently near that perhaps his composition would be a history of the entire world. ${ }^{66}$ As one would expect, much of this apocalyptic language centers around the fall of Baghdad to the Mongols and the murder of

63 God destroyed the people of Thamud (Quran 11:61-8) during the pre-Islamic period.

64 Juzjani, Tabaqat, ii, pp. 713-16.

65 Ibn Abi al-Hadid, Sharh Nahj al-balagha (Beirut: Dar al-Jil, 1987), viii, pp. 215-43, especially $215-8$.

66 That this is the case is strongly indicated by his note concerning the traditions that the world would come to an end at the Muslim year 500 [1106] (al-Fitan wa-l-malahim, i, p. 25). He notes that this tradition was a correct one, but that God had granted a stay for a limited time. Since he was writing in approximately 1370 , he seems to have been conscious of living on borrowed time. 
the caliph, which he compares to the destruction of the Temple (cf. Quran $17: 4-8) .{ }^{67}$

\section{c. Apocalyptic Qur'anic interpretations}

For centuries prior to the Mongol invasions, verses concerning Gog and Magog had been well known from the Quran (18:94, 21:96) that prophesied a deluge of peoples from the east upon the Muslim world, destroying it utterly. ${ }^{68}$ The Qur'anic verses read as follows:

"They said: 'O Dhu al-Qarnayn, surely Gog and Magog are making mischief in the land. Shall we pay you a tribute so that you may build a barrier between us and them?" (18:94) and "Until Gog and Magog are let loose, and they slink away from every quarter." (21:96) ${ }^{69}$ Both of these verses are related closely to the widespread Alexander Romance legends, which tell of Alexander the Great's construction of a wall or barrier to prevent Gog and Magog from attacking the rest of the world. Accusations of an identification with Gog and Magog by Muslim exegetes would indicate that the Mongols were irredeemably evil (since Gog and Magog were considered to be non-Muslim, almost animal, people) and are therefore in a completely different category than identifications with the Turks (however pejorative) listed above.

Once again, Ibn Kathir tends to be the most direct in this regard. His commentary on 21:96 gives us most of the traditions already cited above, and he freely mixes the materials on Gog and Magog with the Turkish traditions. ${ }^{70}$ But unlike in his apocalyptic book cited above Ibn Kathir is not so rash as to identify Gog and Magog of the Qur'an with the Mongols. The reasons for this are probably that the order in which apocalyptic events were to happen according to Muslim apocalyptic writers dictated that Gog and Magog finish off humanity to a large extent. Ibn Kathir does cite one tradition "People will make pilgrimage and the lesser pilgrimage after the appearance of Gog and Magog,",71 however, in general civilization was supposed to be coming to a close. While Ibn Kathir almost certainly believed that he was living close to the end of the world, he might have hesitated to actually identify a group that had clearly dissipated by his time with an event that was usually interpreted as being the penultimate event in the world's history. Most other commentators following Ibn Kathir

67 Ibn Kathir, al-Bidaya wa-l-nihaya (Beirut: Maktab al-Ma'arif, n.d.), xiii, pp. 200-4, especially p. 202-3.

68 For a summary, see Studies in Muslim Apocalyptic, pp. 182-8.

69 Qur'anic translations are from Majid Fakhry, The Qur'an: A Modern English Version (London: Garnet Press, 1997).

70 Ibn Kathir, Tafsir al-Qur'an al-'azim (Beirut: 'Alam al-Kutub, 1993), iii, pp. 190-2.

71 Ibid, p. 191. 
were similarly cautious. ${ }^{72}$ In general, Muslim scholars were much more willing to write about contemporary attitudes towards events in their historical or apocalyptic books than they were in exegesis of the Quran. ${ }^{73}$

\section{Conclusions}

One must ask the question constantly: to what extent can one rely upon the historians of this time? It may very well be that their descriptions of the Mongols were made to be in accordance with the well-known descriptions of Gog and $\mathrm{Magog}^{74}$ in order to communicate their horror at the mass destruction wreaked by the Mongols upon the Muslim world. If this is the case, to what extent can we rely upon the descriptions lavished by Muslim historians of the apocalyptic atmosphere of the times? Perhaps all of it is merely a literary trope designed to communicate these emotions?

Some of that suspicion can be allayed by the examination of the messianic and apocalyptic movements or trends that are datable from this time. For example, the protest movement of al-Tarabi in Bukhara was messianic in the form related by (pseudo-) Ibn al-Fuwati, but much less so in the later Persian account of Khwandamir. While it might be difficult to decide whether the movement was or was not messianic (since one could make the argument that Khwandamir as a member of the elite might not have wanted to emphasize those messianic elements or might have thought that the few hints he gives of the messianic aspect of the movement were enough for his readers), but as a protest movement it cannot be denied. And messianism would have been a plausible response on the part of the Bukharans against the (virtually) invincible Mongols.

Also, the apocalyptic atmosphere of Medina in the immediate wake of the volcanic eruption of 1256 cannot be denied, although it lacked any focus (a messiah for example). But the panic described in the sources was undoubtedly

72 al-Hindi, Kanz al-ummal xi, p. 260 (no. 31455) - while he is deciding whether to give the tradition the mark of daif or not he says (since he is relating it from al-Baghdadi) waqa'at hadhahi al-hurub wa-l-dhabh ba'd mawt al-Khatib bi-akthar min miati sannatin wa-dhalika mima yuqawwi wurud al-hadith [the battles (described) and the slaughter happened more than 200 years after the death of al-Khatib (al-Baghdadi, who died in 1071), and this is what strengthens the provenance of the tradition]. In all likelihood the tradition was first circulated after the siege of Baghdad in 197-98/815-16 by Tahir b. Husayn, the general of al-Ma'mun (see my “The Apocalyptic year 200/815," Apocalyptic Time [Ed. Albert Baumgarten, Leiden: E.J. Brill, 2000], pp. 41-67).

73 See also the Ottoman commentator al-Brusawi, Tafsir Ruh al-bayan (Beirut: Dar al-Fikr, n.d.), vi, p. 372.

74 Comparing Ibn al-Athir, xii, p. 260 with the Gog and Magog traditions already cited. 
real, and generated at least partly because of the conjunction of the Mongol conquests (perhaps identified with Gog and Magog in the popular mind) and the known sign of the volcanic irruptions.

It is not surprising that the Mongols appear in the Muslim sources as a demonized entity related to various horrifying apocalyptic groups. The apocalyptic identifications there gave a context to their depredations, but faded quickly from the literary and historical materials after the Mongols had passed from the scene. 